\title{
A exaltação de Jesus em FI 2,9-11
}

\author{
Orientador: Isidoro Mazzarolo \\ Mestrando: Jackson Willian Marques da Fonseca \\ Área de Concentração: Teologia Bíblica
}

Linha de Pesquisa: Análise e Interpretação de Textos do Antigo e Novo Testamento

Fl 2,6-11 é texto fundamental na cristologia do cristianismo primitivo e neotestamentária. Inserido na parênese da carta de Paulo aos Filipenses, a passagem desenvolve uma narrativa cristológica que começa na preexistência, passa pela encarnação e culmina na exaltação de Jesus. No contexto da carta funciona como um chamado ético aos que estão "em Cristo" à obediência ao Senhor exaltado. Literariamente o texto é um hino composto de duas partes: 2,6-8 e 2,9-11, e a leitura proposta é ver nesta segunda seção o centro do hino, que justamente trata da exaltação de Jesus. O tema da exaltação, é apresentado dentro de uma perspectiva escatológica, pois o início do senhorio de Jesus é o cumprimento da esperança israelita no triunfo de Deus, é a virada escatológica que traz o tempo de salvação. Através da exaltação Deus compartilhou com seu Filho a soberania sobre o universo, implicando que todos os seres precisam agora dobrar os joelhos diante de Jesus e reconhece-lo como Senhor. Aqueles que já fazem isso voluntariamente vivenciam antecipadamente o que será a realidade escatológica final. Esse novo papel de Jesus é descrito pelo título kúpıs, que combinado com outros elementos do texto atribui a ele contornos divinos e de igualdade com YHWH, além de uma oposição às ideologias romanas. A exaltação de Jesus também está ligada com a revolução cristológica que aconteceu no culto cristão primitivo, quando os cristãos judeus adoraram Jesus ao lado de Deus Pai, sem renunciar ao seu monoteísmo. O final do hino enfatiza exatamente que a exaltação de Jesus foi conduzida por Deus e resulta em sua própria glória.

Palavras-chave: Exaltação de Jesus. F1 2,9-11. Senhor. 